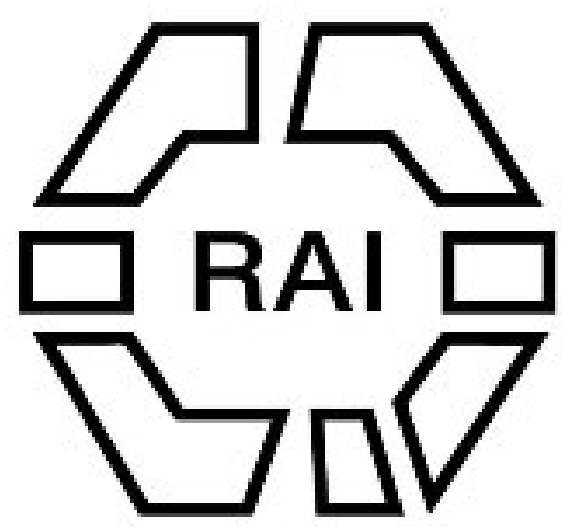

Nudity in India in Custom and Ritual.

Author(s): W. Crooke

Reviewed work(s):

Source: The Journal of the Royal Anthropological Institute of Great Britain and Ireland, Vol. 49 (Jul. - Dec., 1919), pp. 237-251

Published by: Royal Anthropological Institute of Great Britain and Ireland

Stable URL: http://www.jstor.org/stable/2843441

Accessed: $26 / 11 / 201221: 16$

Your use of the JSTOR archive indicates your acceptance of the Terms \& Conditions of Use, available at http://www.jstor.org/page/info/about/policies/terms.jsp

JSTOR is a not-for-profit service that helps scholars, researchers, and students discover, use, and build upon a wide range of content in a trusted digital archive. We use information technology and tools to increase productivity and facilitate new forms of scholarship. For more information about JSTOR, please contact support@jstor.org. 


\section{NUDITY IN INDIA IN CUSTOM AND RITUAL.}

By W. CRooke, C.I.E., Hon. D.Sc. Oxon.

THE costume of the people of India, like that of all residents in tropical countries, is generally scanty; but they cannot be described as a naked people, or careless of personal modesty. On the contrary, in Northern India at least, they are careful to cover those parts of the person which it is indecent to expose. Anyone who has seen women, covered with a single sheet, come dripping out of the water at a bathing festival, will remark the care and dexterity with which they change their wet clothing. Little children, it is true, up to the age of four or five years may be seen nude, and any attempt to cover the person, by a bead or some other amulet hung from the waist, or, in the case of girls by wearing a kind of fig-leaf, often made of silver, is intended as a prophylactic rather than as a concession to public opinion.

There are, or were in recent times, certain tribes among whom the habit of absolute nudity prevailed; but the number of such instances is rapidly disappearing among the more primitive races as they gradually come under the influence of Hinduism. The case of the Juāngs of Chotā Nāgpur is familiar from the description and photographs of them given by Colonel E. T. Dalton. ${ }^{1}$ The Semas of Assam are practically naked, as the small flap worn hanging from their waists cannot be said to hide their nakedness, and the same is the case among some Bhīls of Gujarāt. ${ }^{2}$ Nudity, or semi-nudity, is more common among some of the wilder tribes of the South. Some of the Porojās or Parjās of the Vizagapatam and Ganjam Districts on the East Coast wear a loin-cloth of fibre, so scanty that they are obliged to sit on their heels, for decency's sake, instead of squatting in the usual position. ${ }^{3}$ The Yānādîs are almost nude, carrying palm-leaf baskets dangling from their waists, in which they collect forest bulbs, dead rats or snakes, which they eat. ${ }^{4}$ The Chenchūs accentuate their nudity by wearing a narrow bark thread round the waist to hold their arrows and a knife. ${ }^{5}$ Both the Kādirs and the Vedans are said to have gone

1 Descriptive Ethnology of Bengal, 155 et seq. The Phyllitæ or "leaf-clad" people described by Ptolemy (vii, 66) have been identified with the Bhils or Pulindas, while some tribe in the neighbourhood of the Vindhyan range may be identified with the Parna-Savaras, or "leaf-clad" Savaras. Archooological Survey Reports, ix, 151 ; xvii, 127 et seq.

2 Census Report, Assam, 1891, i, 246 ; Bombay Gazetteer, ix, Part i, 297.

${ }^{3}$ E. Thurston, Castes and Tribes of Southern India, vi, 219.

4 Ibid., vii, 432.

5 Ibid., ii, 34. 
naked when they were first observed by Europeans. ${ }^{1}$ Among the wild tribes of Upper Burma men of the Pa-hlaing Karens were not taxed by the native Government until they began to wear clothing, and, in order to escape taxation, it was the custom for young men to go about mother-naked until at least the age of twenty. In hot weather Wā men and women never wear any clothing, or only on ceremonial occasions; at other seasons they wear a strip of coarse cotton cloth, an absolutely inadequate dress. ${ }^{2}$ Left to themselves, the Andamanese and Nicobarese go stark naked, and do not cover the head. ${ }^{3}$

The custom which prevails among high castes, like the Nāyars in Southern India, where women wear no covering for the bosom, is startling to a visitor from the North, where all women wear some kind of bodice. It is part of the general etiquette in that part of the country, for a description of which I am indebted to Mr. F. J. Richards: "In the Tamil country, i.e., from the Kaveri valley southward and east of the West Ghāt range, the conventional dress of the upper classes is, first, a loincloth (vesshti, the dhoti of the North), and secondly, a body-cloth (anga-vastiram). The lower classes commonly wear only the perineal cloth (komanam) and a second cloth which they wear only for convenience on the head, round the waist, or across the shoulder. The body-cloth is ordinarily worn across the shoulder and diagonally across the body, but it can be shifted according to convenience or fancy. Officials, Vakils or lawyers, and others who by official etiquette are required to cover head and body, wear the body-cloth over the coat, and also a turban, generally one ' made up' with a pith basis. Social and religious etiquette in the Tamil country prescribes that head and body down to the waist should remain uncovered in the presence of a superior. Thus, a Brāhman should go 'bare-bodied' when he enters the more sacred precincts of a temple, when he escorts his spiritual guide or Guru, and in the presence of his god or Guru he should wear his body-cloth round his waist. If a cultivator or a cooly sees an official coming towards him, or on entering a Court of Justice, he should take his cloth from off his head or body, if he is so wearing it, and tie it round his waist before entering 'the Presence.' A relic of this practice is no doubt the basis of the etiquette in the presence of H.H. The Mahārājā of Mysore, at whose Darbārs only a few of the highest officials, such as the Dīwān, Councillors, or Judges of the High Court, are permitted to wear the body-cloth across the body and over theshoulder : all others, not so privileged, wear this cloth round the waist. The Tamil practice appears to be a compromise between Malabar custom and Muhammadan etiquette."

In the ancient Tamil period " a full dress appears to have been the outward

1 E. Thurston, Castes and Tribes of Southern India, iii, 12 ; vii, 332.

2 (Sir) J. G. Scott, J. P. Hardiman, Gazetteer, Upper Burma and the Shan States, Part i, Vol. i, $545,510$.

3 Census Reports, 1901, 56, 198; 1911, 120; Journ. Roy. Anthrop. Inst., vii, 439; xii, 329 
sign of a servant rather than of a master; and the nobles put on only so much clothing as can be worn without inconvenience in a hot climate. In the ordinary dress of the Tamil woman, the shoulders, arms and body down to the waist were entirely bare, the drapery descending from the loins downwards to the ankles. The part of the body which was left uncovered was generally adorned with sandal and other fragrant powders. The Nāga women appear to have been almost naked, like those depicted in the Amarāvatī sculptures. The courtesans wore a piece of muslin which covered their body from the waist to the middle of the thigh; but it was such fine texture that it hardly concealed their person."1 In the Mysore ancient basreliefs "women are commonly arrayed in nothing more than rows of ornamental chains and jewellery, pendent from the throat and loins-an attire, if such it may be called, worthy of the Age of Innocence; and becoming enough, it may be, on the golden-olive and nut-brown tints, that hardly reveal a blush, of Nature's vesture for the fair of these climes."2 Marco Polo writes: "You must know that in all this Province of Maabar there is never a Tailor to cut a coat or stitch it, seeing that everybody goes naked. For decency only they do wear a scrap of cloth; and so it is with men and women, with rich and poor, aye, and with the King himself, except what I am going to mention. It is a fact that the King goes as bare as the rest, only round his loins he has a piece of fine cloth. . . . The people of the country go to battle all naked, with only a lance and a shield."’3

This Dravidian custom of semi-nudity is found among some of the forest tribes, by whom, in the case of women, it is not considered a mark of indelicacy ; in fact, the Gonds used to forbid their women to wear the little jacket (choli). In Bastar, however, women of this tribe are said to be giving up the custom of exposing their bodies above the waist:4 Abor and Kandh women leave the part of the body above the waist uncovered. ${ }^{5}$ The Pallan women of Tanjore are said to dress in this way, "a distinctive mark of their primitive condition of slavery, of which, however, no trace now exists" ; but this is certainly a mistake, because the practice is common among the higher castes of South India, except foreigners like the Nambūtirī Brāhmans. ${ }^{6}$ Another fact pointing in the same direction is that Tiyan women were not allowed to wear anything above the waist, except when under death pollution. ${ }^{7}$

A crisis arose in Travancore in 1858, when riots occurred because Shānān Christian converts gave up the practice of going about without an upper cloth.

1 V. Kanakasabhai, The Tamils Eighteen Hundred Years Ago, 117.

2 B. L. Rice, Mysore, ed. 1897, i, 215.

3 Marco Polo, ed: Sir H. Yule, lst ed., ii, 274 et seq, 278.

4 R. V. Russell, Tribes and Castes of the Central Provinces, iii, 123, 131.

5 Dalton, op. cit., 27, 301.

6 Thurston, op. cit., v, 474 ; L. K. Anantha Krishna Iyer, The Cochin Tribes and Castes, ii, 100.

7 Ibid, op. cit., vii, 98. 
The matter was settled by the Mahārājā, following the lead of Sir C. Trevelyan, Governor of Madras, byissuing a proclamation which legalized the practice of these converts in maintaining their efforts to encourage modesty in dress. ${ }^{1}$

In Northern India, in the carvings on Buddhist Stūpas, women, particularly, it would seem dancers or attendants, are depicted nude above the waist. ${ }^{2}$ But, according to General Maisey, "there is no question as to the nudity of the women in this sculpture ; but it is quite a mistake to suppose that nudity is the rule among the female figures at Sānchi. Some who appear, on a cursory glance, to be totally nude, only appear so because the sculptor, like the early Greek artists, represented thin drapery, over the lower limbs, by simple lines. In figures, however, whose attitudes necessitate it, the drapery is fully shown."'3

The next stage is the wearing of bark clothing. There does not appear to be any reference to this custom in Vedic literature; but the ancient Hindu ascetics used to dress in this material, and so, according to Strabo, did the Hylobioi, who seem to represent the Vanaprasthas or Hindus in the third, or ascetic, stage of life. ${ }^{4}$ In the Rāmāyana epic Rāma and Sìtā in their wanderings through the Vindhyan hills wore raiment of bark; the Pāndavas, exiled to the Himālaya, wore the same clothing, and in the Panjābī tale of the Saiva cult of Mahāsū Deotā, the Brāhman Hūnā throws aside his clothes and dons bark attire. ${ }^{5}$ Bark dresses continued to be worn in mourning at the time of Harsha of Kanauj in the beginning of the seventh century A.D. ${ }^{6}$ Its use has not quite disappeared in modern times. Within the last fifty years the Gadabas of the Central Provinces used to wear a cloth made from the bark of the Karing tree, with horizontal bands of yellow, red and blue. ${ }^{7}$ The hill Pandārams of Travancore live in caves and hollow trees, and wear bark clothing. ${ }^{8}$ Porojā or Parjā women in the Vizagapatam and Ganjam Districts on the East Coast wear a scrap of bark or cotton cloth, about a foot square, attached to the waist by a string; they say that they are obliged to wear this clothing, because some of their ancestors jeered at Sìtā for wearing this dress, and she cursed them that they should wear nothing else. ${ }^{9}$ The Chinbous of Upper Burma are said to wear bark occasionally, but the majority of them appear to wear nothing. ${ }^{10}$

1 Thurston, vi, 365 ; V. Nagam Aiya, State Manual of Travancore, ii, 222.

2 (Sir) A. Cunningham, The Bhilsa Topes, Plate xv, 206, 213 ; The Stupa of Bharhut, 33 ; F. C. Maisey, Sanchi and its Remains, 35.

3 Maisey, op. cit., 22.

4 Manu, Laws, xi, 102, 106 ; Strabo, xv, 59 ; J. W. McCrindle, India as described by Megasthenes and Arrian, 98, 102 ; (Sir) A. Cunningham, The Stupa of Bharhut, 30.

5 R. H. Griffith, The Ramayana, ed. 1895, p.138 f. ; E. T. Atkinson, Gazctteer of the Himalayan Districts of the North-West Provinces, ii, 281; H. A. Rose, Glossary of Tribes and Castes of the Punjab and North-West Frontier Province, i, 405.

6 Bana, Harsa Charitra, 173.

7 C. Grant, Central Provinces Gazetteer, 1870, p. 33.

${ }^{8}$ Census Report, Travancore, 1901, i, 353 ; V. Nagam Aiya. op. cit., ii, 417.

9 Thurston, op. cit, vi, 212 et. seq

10 Scott, Hardiman, op. cit., Part i, Vol. i, 461 
Andamanese women are said to wear bark of the Celtis vestimentaria tree, but Sir G. Watt does not mention this tree as a source of the clothing. ${ }^{1}$ The use of bark clothing among the Veddahs of Ceylon seems to have generally disappeared, but among the Coast branch of the tribe dancers should wear a petticoat made of coco-nut leaves and green twigs of other trees. ${ }^{2}$

The chief source of bark clothing, Sterculia guttata, is found, not in North India, but in the east and west of the southern part of the Peninsula, in Ceylon and the Andaman Islands. ${ }^{3}$ In the north the use of the bark of the Betula bhojpattra for literary purposes dates from ancient times, and it continued to be employed until the manufacture of paper was introduced by Akbar, from whose reign its use for writing purposes was discontinued, and the method of preparing it has been lost.4 But birch bark continued to possess some traditional importance, as women in Bengal in the beginning of the nineteenth century used to wear charms written on it when they desired children. ${ }^{5}$

The use of leaves for clothing is more common than that of tree bark, and like that, its employment for this purpose prevails specially in Southern India. Among the Tandu Pulayans of Travancore men now wear the ordinary waist-cloth, but the distinctive name of this section of the tribe is derived from the women's dress, which consists of the leaves of a kind of sedge, cut into lengths a foot long and tied in a bushy tail behind and before. Young girls wear at first a strip of bark from the areca palm; later in life they assume the dress of sedge leaves. Both are said to be going out of use, being replaced by cloth. ${ }^{6}$ In British territory in Madras the Vettuvan women wear only leaves round their waists, and renew them daily; in some cases this dress is so far varied that their double fan-shaped apron of leaves is tied round the waist with a cloth girdle. ${ }^{7}$ Men of the Koragā tribe, who are regarded as foul outcasts, wear a loin-cloth, the women leaves woven together. ${ }^{8}$ When F. Buchanan made his expedition about the year 1800, women of the Korar or Koravā tribe in Mysore stuck a bunch of leaves into a girdle fore and aft. Some of the men had a fragment of cloth round their waists, but few of the women were able to procure this. Those of the same tribe in British territory, who are known as

1 Census Report, 1901, 170.

2 C. G. and B. Z. Seligmann, The Veddas, 34, 213, 337.

3 (Sir) G. Watt, $A$ Dictionary of the Economic Products of India, vi, Part iii, 363. For methods of making bark cloth, see W. W. Skeat, C. O. Blagden, The Pagan Races of the Malay Peninsula, i, 375 et seq.

4 Watt, op. cit., i, 452 et seq.

5 W. Ward, The Hindoos, 2nd ed., i, 155.

6 Census Report, Travancore, 1901, i, 341 ; V. Nagam Aiya, op. cit., ii, 404 ; E. Thurston, Ethnographic Notes in Southern India, 66 ; W. Logan, District Manual of Malabar (i, 148), calls these people Cheruman (see E. Thurston, Castes and Tribes of Southern India, ii, 45 et seqq), and mentions their custom of wearing bark.

7 Thurston, Castes and Tribes, vii, 395 et seqq.

8 Ibid., iii, 428 et seq. 
Yerukalās, seem to have adopted the normal Hindu dress. ${ }^{1}$ Some leaf-wearing tribes are found in Orissa. The Malhärs wear bunches of green leaves attached to a number of strings round the waist. Not long ago the leaf-wearers in Keunjhar were induced by a British officer to accept cotton clothes; they were marked by him on their foreheads with vermilion as a sign of their admission into civilized society. The women then burned their bunches of leaves, and the men took an oath that they would never allow their women to wear them in future. ${ }^{2}$

In the Andaman Islands women of the Bojigngiji section wear a bunch of five or six leaves in front; Yerawā women a loose tassel made of strips of various kinds of bark; the Ongī-Jarawās a bunching tassel of fibres, while the Jarawā women are apt to be quite unclothed. ${ }^{3}$

The use of dress of this kind necessitates the wearing of the girdle, and this emphasizes the importance of it in the evolution of Indian dress. Early accounts of the Māriā section of the Gonds describe their dress as consisting of a girdle of cowry shells or of ten or fifteen cords, attached to which were a tobacco pouch and a naked knife. ${ }^{4}$ According to another account of the tribe in an early account published in 1866, " on the east of Chāndā District the men wear no covering for their head or for the upper part of their bodies, and constantly go about with a battleaxe in their hands. The women deck themselves with thirty or forty strings of beads, to which some add a necklace of pendent bells. Bangles of zinc adorn their wrists, and a chain of the same metal is suspended from the hair and attached to a large boss stuck in her ear. But the greatest peculiarity connected with this costume is the practice which prevails in the more remote districts, of the women wearing no clothes at all ; instead of which they fasten, with a string passing round their waists, a bunch of leafy twigs to cover them before and behind."5 According to Dalton though the Orāon man wears a loin-cloth he always has round his, waist a girdle of cords made of tusser silk or of cane: "This is now a superfluity, but it is no doubt the remnant of a more primitive costume, perhaps the support of the antique fig leaves."6 At present the young man's girdle is of twisted cotton thread dyed black, or of the fibre of a creeper, from which keys, a purse, and thorn tweezers are hung, or a bamboo flute is stuck in it. ${ }^{7}$ Chin women in Upper Burma keep the skirt in place by a brass or iron girdle, like the chain of cog-wheel, and from three to four pounds in weight. The men wear a string round the waist from which a strip of cloth hangs down in front and is looped up behind, but in addition they

1 F. Buchanan, A Journey from Madras through the Countries of Mysore, Canara and Malabar. iii, 100 ; Thurston, op. cit., iii, 501.

2 (Sir) W. W. Hunter, Orissa, ii, 68, 116 et seq.

3 Census Report, 1901, p. 50.

4 Dalton, op. cit., 279.

5 S. Hislop, Papers relating to the Aboriginal Tribes of the Central Provinces, 8.

6 Dalton, op. cit., 279.

7 Sarat Chandra Roy, The Orāons, 93. 
have a sort of apron, often ornamented with beads or shells, and reaching half-way to the knee, this indicating a progressive development in dress. ${ }^{1}$ In the same way, every woman of the Halbā, a cultivating caste in Raipur District of the Central Provinces, must have a thread round her waist, which in the old days probably held up an apron of leaves. ${ }^{2} \quad$ This enables us to understand the importance of the girdle in ancient times, as is shown in the Buddhist sculptures, of which Cunningham gives an account, one name for this article of dress indicating that it was made of the seeds of the Abrus precatoria, or Indian wild liquorice, and these were gradually superseded by beads made of the precious metals. ${ }^{3}$

The semi-nudity of some Ascetic Orders at the present day is familiar to all observers of Indian life; but the ancient practice of ascetics appearing naked in public has been gradually reformed by British law and by the growth of a healthier feeling among Hindus. F. Bernier, writing about the middle of the seventeenth century, states that numbers of the Jauguis, or Jogis, " are seen day and night seated or lying on ashes, entirely naked : frequently under the large trees near $t \bar{a} l \bar{a} b s$, or tanks of water, or in the galleries round Deüras, or idol temples."4 Members of one of the highest Orders, that of the Paramahansās, still go naked. ${ }^{5}$ When Professor Oman visited the great ascetic, Swāmi Bhāskaranandā, he found him sitting naked, and the same rule is followed by other Saiva ascetics-Dandīs, Khākīs, and Nānga Sannyāsiss, and by Vaishnava Bairāgīs. ${ }^{6}$ Some years ago an application was made to the High Court, Bombay, with the object of cancelling an order made by a magistrate prohibiting Saiva Gosāīns or Gosvāmīs from walking naked in procession at the sacred city of Nāsik in the Deccan, and it was pleaded that bathing naked had always been allowed at pilgrimages to Hardwār and Allāhābād. This assertion is certainly untrue at the present day. The application was rejected.7

The question of the origin of enforced nudity in the various forms of ritual and magic is not free from difficulty. As Dr. E. Sidney Hartland remarks, it may in some cases be based on the belief in the apotropæic powers attributed to the sexual organs. 8 In many places high caste women or girls in times of drought are in the habit of divesting themselves of their clothing at night and dragging a plough through the fields, men being carefully excluded during the rite. ${ }^{9}$ When rain fails the

1 Scott, Hardiman, op. cit., Part i, Vol. i, 469 ; Part ii, Vol. i, 245.

2 Russell, op. cit., iii, 199.

3 Stupa of Bharhut, 37.

4 Travels in the Mogul Empire, ed. 1914, p. 316.

5 W. Ward, The Hindoos, 2nd ed., ii, 375 ; H. H. Wilson, Sketch of the Religious Sects of the Hindus, i, 231 et seq; Jogendra Nath, Bhattacharya, Hindu Castes and Sects, 385; J. C. Oman, Mystics, Ascetics, and Saints of India, 162.

${ }^{6}$ Oman, op. cit., 161, 189, 206, 224 ; Rose, op. cit., ii, 215 ; iii, 357 ; Wilson, op. cit., i, 238 et seq.

7 Oman., op. cit., 269.

8 J. Hastings, Encyclopcedia of Religion and Ethics, ix, 830.

๑ Sir James Frazer, The Golden Bough, 3rd ed., "The Magic Art," i, 275. 
Meitheis of Manipur, headed by their Rājā, strip off all their clothes, and stand cursing each other in the streets of Imphäl, the capital town, while women strip themselves at night and throw their rice-pounders into the river. ${ }^{1}$ The popular explanation of such practices is that the custom of high caste women sharing in the ploughing, or of a Rajjā violating the common laws of decency, is such a subversion of the existing order of things that Indra or some other rain-god is moved to pity and grants the desired rain. This is clearly an ex post facto explanation. The action of water as an agency in causing fertility is a commonplace of folk belief. ${ }^{2}$ In the Panjāb on a Sunday or Tuesday night, or during the Divālī, or feast of lights, a barren woman desiring a child sits on a stool, which is then lowered down a well. After divesting herself of her clothes and bathing, she is drawn up again and performs the Chaukpürn $\bar{a}$ ceremony with incantations taught by a wizard. Should there be any difficulty about descending the well, the ceremony is performed beneath a sacred $p \bar{\imath} p a l$ or fig-tree. It is believed that after such a ceremony is performed the well runs dry and the tree withers, the Mana of both having been exhausted during the rite. ${ }^{3}$ In similar cases of rain-magic the girls are clad in leaves to symbolize vegetation. We may suspect that the performers in such rites of rain-magic divest themselves of their clothes in the expectation that the rain will immediately fall and fertilize them, and through them the thirsty vegetation.

As regards the custom of nudity by the religious Orders, it symbolizes death to this world, the renunciation of all family and social rites. In the case of nudity in ritual, of which examples will be given, the case is not so clear. When the Badāwī in the days of heathendom used to make the ceremonial circuit of the Kaaba at Mecca naked, or wearing clothes borrowed from one of the religious communities of the holy city, the explanation is that if the worshipper wore his own clothes, they became harim or taboo through contact with the holy place or function.4 This belief does not appear to prevail among the Hindus, and the motives for the disuse of clothes in religious or magical rites seem to be varied : partly, the dread of the pollution which may arise from clothing during the rite; partly, the tradition of purity attaching to the Brāhmans of ancient days, who lived as naked ascetics in the forest. In this connection it may be noted that the Nambütiri Brāhmans of Malabar, who affect to regulate their lives according to the ancient Vedic rule, are, in the case of men, very sparing in the use of clotbing, and do not seem to feel ashamed at being seen walking about almost naked. On the other hand, a Nambütiri in the ascetic (vanaprastha) stage of life should not eat quite naked. ${ }^{5}$

1 T. C. Hodson, The Meitheis, 108.

2 E. S. Hartland, Primitive Paternity, i, 64 et seqq.

3 Census Report, Panjab, 1901, i, 164; another version of the rite is recorded in Panjab Notes and Queries, iv, 58.

1. W. Robertson Smith, Lectures on the Religion of the Semites, 2nd ed., 481.

${ }^{5}$ L. K. Anantha Krishna Iyer, op. cit., ii, 280, 286. 
Instances of nudity in magical or religious rites are not uncommon. At the famous ice-cave shrine of Amarnäth, "the undying Lord," a form of Siva, until recent times, pilgrims, men and women, on entering the cave used to strip off their clothing; it was believed that Siva wished them to appear nude and dance before him. The Mahārājā of Kashmīr, however, directed that women were to cover themselves, but only with a single garment. At present the men enter wearing only breech-clouts, but when inside each man divests his neighbour of his cloth, and in the end all stand in the cave stark naked. According to Vigne, some pieces of birch-bark were used as fig-leaves. Dr. Neve states that the worshippers throw themselves naked upon the ice block in the cave which represents Siva. ${ }^{1}$ According to Sir Walter Lawrence ${ }^{2}$ the rite is performed at the full moon of the month Sāwan (July-August), when pilgrims worship the snow lingam, which gradually melts away after this full moon. "Strict Hindus, both male and female, will discard their clothes and put on shirts of birch-bark before they enter the cave." As regards the nude dance in honour of Siva, a legend current in the Himālaya tells that the wives of the Rishis or deified saints used to dance naked before Siva-Mahädeva. ${ }^{3}$ A century or so ago votaries of the goddess Sarasvatī, goddess of learning, and of Devī, the mother goddess, in her form as Jagaddhātrī, "fosterer of the world," used to dance naked in processions at Calcutta." At the fair held at Devidhāra in Kumaun in the lower Himallaya, the idol used to be dragged to the top of the bill by stark naked men. ${ }^{5}$ It is probably an instance of the taboo supposed to be caused by touching sacred things that, in the case of the Gond deity, Pālo, whose image is made of cloth and used as a covering for the sacred spear-heads, the Katiā or Rāj Pardhān, the tribal priest, who is entrusted with the task of making the image, must live in a separate house, must not approach his wife until the work is finished, and while he is engaged upon it he must remain naked. ${ }^{6}$ Nudity is sometimes enforced in the performance of a vow, as is the case in Gujarāt, when a child is attacked with small-pox the mother vows to prostrate herself naked before the small-pox goddess either from her own house or at a short distance from the temple.?

Some of the Jain Orders prescribe nudity for their priests. There are two Orders, the Digambara, "those clad only in the sky," the Svetāmbara, or "whiterobed." In the case of the former the images of the Tinrthakaras, or deified saints, have no eyes and wear no loin-cloth, and their priests are confined to monasteries,

1 F. Drew, Jummo and Kashmir Territories, 222 ; (Sir) W. R. Lawrence, The Valley of Kashmir, 41 ; Oman, op. cit., 268 et seq.

2 Op. cit., 265 et seq.

3 Atkinson, op. cit., ii, 303.

4 Ward, op. cit., ii, Introd. xxix, xxxvi, 103, 137. Compare the dancing of David before the Ark, 2 Samuel vi, 14, 20.

s Atkinson, op. cit., ii, 201 et seq.

${ }^{6}$ Russell, op. cit., iii, 100.

7 Bombay Gazetteer, ix, Part i, 371.

vol. XLIX. 
where they live in a state of nudity. Among the Svetāmbaras the image has gold eyes, and a representation of a piece of cloth is carved round its loins. In Mysore the Digambara Yatis, or members of the sacred Order, wear a yellow robe which they remove only when eating food. ${ }^{1}$ The remarkable nude Jain images in Mysore and the British District of South Kanara deserve mention. ${ }^{2}$ In Mysore the Bombolas, priests of the Ladar caste, go about naked and offer annual sacrifices to their goddess Bhavānī. ${ }^{3}$

The nudity rites practised by the Sākta sect, worshippers of the female energy, do not admit of description.*

Nudity in ritual naturally is associated with fertility rites. Women who desire offspring walk naked 108 times round a sacred pīpal tree (Ficus religiosa), winding a cotton thread round the trunk. Trees surrounded with such threads may be noticed at the bathing Ghäts in places like Benares, where, of course, the nudity part of the rite is omitted. This circuit in a nude state is often done after worshipping Mārutī or Hanumān, the monkey god, a fertility deity. Among the Kunbīs of the Central Provinces "a variation of the belief is that pippal trees are inhabited by the spirits of unmarried Brāhman boys, and hence a woman sometimes takes a piece of new thread and winds it round the tree, perhaps with the idea of investing the spirit of the boy with the sacred thread. She will then walk round the tree as a symbol of the wedding ceremony of walking round the sacred post, and hopes that the boy, being then brought to man's estate and married, will cause her to bear a son. But modest women do not go naked round the tree."5 This theory savours of Brähmanical interpretation, and it seems very doubtful if the idea of propitiating the spirit of a boy'is present in the mind of the celebrant. It is preferable to believe that, on the analogy of tree marriages, ${ }^{6}$ the woman makes the circuit in the course of the sun of the sacred tree in the belief that she thus brings herself into communion with it and imbibes some of its fertilizing qualities. In Bombay, women desiring children go to a temple of Hanumān, the monkey god, strip themselves naked and embrace the image. ${ }^{?} \quad$ In the United Provinces a woman who is childless stands naked facing the sun, and invokes his aid to cure her barrenness, or rather to rid

1 Bombay Gazetteer, ix, Part i, 105 ; B. L. Rice, Mysore, i, 462 ; Russell, op. cit., ii, 100 ; Rose, op. cit., i, 104.

2 V. A. Smith, History of Fine Art in India and Ceylon, 268. Hindu temple images are usually decently draped, but there are exceptions. Battā] Bhaurammā is the naked mother goddess of the Deccan; Sitală, the goddess of small-pox, is sometimes represented sitting naked on an ass. In Bengal, Siva in his form Mukutakesin, "he with the flowing hair," is naked, and so is a Nāginī, or female serpent deity in Buddhist art.-Bombay Gazetteer, xxiii, 656. Ward, op. cit., ii, 15, 104 ; Cunningham, Stupa of Bharhut, 26.

3 Census Report, Mysore, 1901, i, 529.

4 H. H. Wilson, op. cit., i, 247 ; Jogendra Nath Bhattacharya, op. cit., 409 et seqq.; Ward, op. cit., ii, 193 et seqq ; Sir M. Monier-Williams, Brähmanism and Hinduism, 4th ed., 184 et seqq.

${ }^{5}$ Russell, op. cit., iv, 32 et seq.

6 Sir J. G. Frazer, The Golden Bough, 3rd ed., "The Magic Art," i, 40 ; ii, 26, 56, 100, 316 et seqq.

7 Panjab Notes and Queries, i, 87. 
her of the evil spirit which has beset her and prevents conception. ${ }^{1}$ It is perhaps due to the feeling of taboo from wearing clothes in a sacred function, or as a fertility rite, that among the Orāons the novices are naked. ${ }^{2}$

In Southern India Ganesa, the god who favours enterprises of all kinds, is worshipped in secret by women; no males, not even babies at the breast, are admitted. They are stark naked during the rite, they must eat then and there the offerings made to the god, and no male is allowed to touch the sacred food. ${ }^{3}$ In the same District the Pambā caste worship the Mother goddesses, Rengāyiammā and Polayāmmā. Women are the chief worshippers, and on one of the nights of the Pongol festival, held at the winter solstice when the sun is believed to return from his southern journey to bless the land, part of the ritual consists in women exposing themselves. ${ }^{4}$ Women of the Kochh tribe in north-eastern and eastern Bengal dance naked round a plantain stem representing Hudum Deo, a naked and extremely repulsive deity, who is pleased to see nude women dancing before him, and to hear obscene songs, in consideration of which he sends rain and good harvests. Males are strictly excluded at the time of the ceremony. ${ }^{5}$ Possibly we may class as fertility rites certain customs connected with marriage, as when a Kanaujiā Brāhman boy in the Deccan is invested with the sacred thread as an initiation rite preceding his wedding, he is stripped naked, and he and his father are made to stand on two stools with a piece of cloth drawn between them. At a wedding among the Kannadiyans, cattle-breeders and traders in the Madras Presidency, the infant bride and bridegroom are seated naked. ${ }^{6}$ Friar Odoric, who visited India early in the fourteenth century, states, that at Thāna in the Bombay Presidency he saw a naked woman marching before a bride and bridegroom, who were dressed for the occasion, but the morning after the marriage they went naked as before. Whatever may be the value of the statement, such exhibitions would now be punishable under municipal law. ${ }^{7}$

Similar processions of naked people are recorded in many of the earlier accounts of India, but such exhibitions are now seldom observed. ${ }^{8}$ At Sattamangalam, in the South Arcot District, Madras Presidency, at the festival of the local goddess Măriammā, who controls small-pox and other epidemic diseases, the chief rite is the sacrifice of a goat at midnight, the entrails of which are suspended round the neck

1 North Indian Notes and Queries, iii, 35. On the belief in conception by the sun, see Sir J. G. Frazer, The Golden Bough, 3rd ed., "Balder the Beautiful," i, 68 et seqq.

2 Sarat Chandra Roy, op. cit., 242.

3 F. A. Hemingway, District Gazetteer of Trichinopoly, i, 102.

4 Ibid., i, 118. For the Pongol feast, see J. A. Dubois, Hindu Manners, Customs and Ceremonies, 3rd ed., 571 et seqq.

5 Panjab Notes and Queries, iv, 197.

${ }^{6}$ Bombay Gazetteer, xviii, Part i, 169 ; Thurston, op. cit., iii, 207. Compare the Orāon initiation, note 2 above. Among the Wagogo of German East Africa the bride and bridegroom sit nude.-Journ. Roy. Anthrop. Inst., xxxii, 311.

7 Sir H. Yule, Cathay and the Way Thither, i, 60.

${ }^{8}$ Compare the procession in honour of the goddesses Sarasvatī and Jagaddhātrī, p. 245 above. 
of a Totī, one of the menial castes who act as village servants. He marches stark naked round the boundaries of his village. ${ }^{1}$ At the festival of the village goddesses in the Dharwār District, Bombay Presidency, two Mādigās, village menials, strip themselves naked and carry about in a pot the blood of the holy buffalo which has been sacrificed, and sprinkle it as an offering to the evil spirits which abide at the village boundary. At a later stage of the rite one of the Holeyās, another menial caste, of the Poturājā, or "buffalo king," section, strips himself naked, ties a few leaves of the $n \bar{i} m$ tree (Azadirachta indica) which, apparently because of its bitterness, is sacred to the Mothers, round his loins, comes up running like a tiger, pounces on a lamb, tears its throat with his teeth, drinks some of the blood, and then runs with the carcass to the village boundary, possibly as a means of expelling evil from the community and promoting fertility. ${ }^{2}$

Nudity is often regarded as an essential condition for the performance of magical rites. The Silārī in Eastern Bengal is employed to carry out the ceremony of dispersing hailstorms. When he sees a storm approaching he runs out of his house almost naked, and disperses the storm-cloud with his magic wand. ${ }^{3}$ His colleague, the Garpagārī or Garpagarī of the Central Provinces, when a storm is threatened, implores Mahābīr or Hanumān, the monkey god, to disperse the clouds. If this appeal fails, he proceeds to threats, declaring that he will kill himself, and then he throws off his clothes. If her husband happen to be absent at such a critical time, his wife goes and stands naked at the shrine of Hanumān.4 In the Trichinopoly District, when in the rainy season tanks and rivers threaten to burst their banks, men stand naked on the embankments ; and if too much rain falls, naked men point firebrands at the sky, as in the case of rain-magic $:^{5}$ this nudity is supposed to shock the powers that send the rain, and to cause its discontinuance. In the Panjab the magical power of healing disease is often practised in a state of nudity. In the Sirsā District a man can cure a horse attacked by a fit by taking off all his clothes and striking the animal seven times with his shoe on its forehead. In the Jālandhar District paralysis in cattle is cured by a man stripping himself naked and walking round the animal with a wisp of burning straw in his hand. ${ }^{6}$ The Orāon tribe supplies many instances of similar practices. At the time of the rice harvest they practise a solemn rite for driving fleas out of the village, in the course of which young men strip off their clothes, bathe, wrap themselves in rice straw, and march round the houses, where they receive doles of food. A youth initiated into the mysteries of the Bachelors' Hall, strips himself naked and brings water from the sacred well of

1 W Francis, Gazetteer South Arcot District, i, 98.

2 Bombay Gazetteer, xxii, 810 et seq. In North Borneo a naked man wanders through a crowd and women touch him as a fertility rite.-E. S. Hartland, Primitive Paternity, ii, 151.

3 J. Wise, Notes on the Races, Castes, and Trades of Eastern Bengal, 369.

4 Russell, op. cit., iii, 21 et seqq.

5 Page 244 above.

${ }^{6}$ North Indian Notes and Queries, i, 136 ; ii, 64. 
the village. A similar custom prevails at the rite for expelling cattle disease. ${ }^{1}$ The Sakuna Pakshis, a class of mendicants in the Vizagapatam District, carry about roots of a plant which are used as antidotes against the stings of scorpions. This plant should be collected on a new-moon day which falls on a Sunday, and the man who seeks for it cuts his loin-string and collects the roots stark naked. ${ }^{2}$

Nudity is also essential in some forms of black magic and witcheraft. In Gujarāt " to gain control over a spirit the Hindu exorcist goes to a burial-ground alone at midnight on the dark fourteenth day of Aso (October), unearths the body of a low-caste Hindu, and bathes in the river. After bathing, while still naked, he carries the body within a circle cut with a knife or formed by sprinkling a line of water" ; ${ }^{3}$ then he goes on muttering charms and evil spirits of all kinds congregate round him.4 In Upper Burma, among the Taman tribe of the Upper Chindwin river, if a man wishes to turn himself into a tiger he urinates on the ground, strips himself, and rolls on the place which he has wetted. ${ }^{5}$ A strange tale is told in the United Provinces of a noted witch, known as Lonā or Nonā Chamārin, a woman of the caste of leather-dressers. One day all the village women were transplanting rice, and it was noticed that Lonā could do as much work as all her companions put together. So they watched her, and when she thought she was unobserved she stripped off her clothes, muttered some spells, and throwing a bundle of seedlings into the air, each settled down into its proper hole. ${ }^{6}$

Possibly with the view of freeing the spirit of the dead man from any contamination which may be produced from clothing, some tribes and castes bury the corpse naked. Instances of this custom are reported from the Gurāvs, Kirārs, Korkūs, and Kunbis of the Central Provinces and the Deccan ; and from the Koravas, Mālas, and Yerukulas of Madras. ${ }^{7}$

Survivals in ritual, rightly interpreted, are of much interest. ${ }^{8}$ All the world over, sacerdotal and other religious vestments tend to follow the models prescribed by custom which is often immemorial. Thus, in Egypt, the panther's skin, the ancient attire of the head of a family, or of a noble in full dress, dates from the period when the use of skins for clothing was habitual, and in later times it survived as the obligatory vestment for certain orders of priests, or for dignitaries performing

1 Sarat Chandra Roy, op. cit., 150, 221, 223, 254 ; Journ. Roy. Anthrop. Inst., xliv, 346.

2 Thurston, op. cit., vi, 263 et seq.

${ }^{3}$ On these magic circles see W. Crooke, Popular Religion and Folklore of Northern India, ii, 41 et seqq.

4 Bombay Gazetteer, ix, Part i, 418.

5 Journ. Roy. Anthrop. Inst., xli, 306.

${ }^{6}$ W. Crooke, Tribes and Castes of the North-West Provinces and Oudh, ii, 171.

7 Russell, op cit., iii, 180, 491, 564 ; iv, 35 ; Ethnographical Survey, Bombay, Monograph 41, p. 7 ; Thurston, op. cit., iii, 498, 499 ; iv, 273 ; G. Oppert, Original Inhabitants of Bhäratavarsa, p. 203.

${ }^{8}$ R. A. Marett, "The Interpretation of Survivals," Quarterly Review, April, 1919. 
sacerdotal functions of a prescribed nature. ${ }^{1}$ Similar customs are common in India. The Todas still wear bark clothing in some of their rites. ${ }^{2}$ The custom of wearing as clothing the leaves of certain trees and plants is common in the worship of some Mother goddesses in Southern India. In the Salem District, at the worship of the sister deities known as Dodammā and Chikammā, Korubā women of all ages, who have bound themselves by a vow, assemble at night near a sacred tank, divest themselves of all their clothing, bathe, and on ascending the steps from the water, put on loose jackets made of pungam or margosa (Azadirachta indica) leaves. Then fixing lighted lamps made of rice-flour in their dishevelled locks, they march in procession round the temple. Their nearest male relations move with them, forming a sort of bodyguard to protect them from the public gaze. When the third circuit is accomplished they make obeisance to the deity. The rite is believed to ensure the birth of children. ${ }^{3}$ At the Periapalayam festival in the Chingleput District, Madras, in honour of the Mother goddess, Māriammā, the worshippers dress in a garment of freshly gathered margosa leaves attached to their waists by a string ; and at the festival of the village goddess in the Bellary District in the Deccan, the procession is headed by a Mādigā menial, who is naked save for a few margosa leaves." At Yellammā's Hill in the Belgaum District, Bombay, people under a vow appear naked before the goddess, tie margosa branches round their bodies from shoulder to knee, walk round the temple clad in this attire, and again revere the goddess clad in ordinary dress, a robe in the case of women and a loin-cloth for men. ${ }^{5}$ At Jekhapur in the Nimār District, Central Provinces, people who have made a vow discard their clothing, put on aprons of margosa leaves, take a pot of water from a well in the village, ascend the hill by night, worship the goddess Jekhadevi, "she who fulfils prayer," and pour the water over their bodies, apparently as a charm for rain or for fertility. ${ }^{6}$

Social or religious custom, or possibly in some cases the influence of taboo, enforce the habit of nudity. The Miri Nāga men, when working in the fields, wear nothing but necklaces and collarets of beads; in the cool of the evening they wrap themselves in blankets, but wear no loin-cloth. The women, though they seem to be usually covered when in their villages with a short skirt reaching half-way to the knee, are said to doff all clothing when at work in the fields. ${ }^{7}$ In the Godàvarī District, Madras, the Komati women do the cooking in a state of nudity; those who admit the practice say that it is done for the sake of cleanliness, lest the touch

1 G. Maspero, The Dawn of Civilisation, p. 53, note 8.

2 W. H. R. Rivers, The Todas, 573 et seq.

3 F. J. Richards, District Gazetteer of Salem, i, Part i, 121.

- E. Thurston, Ethnographical Notes in Southern India, 364 et seq.; Castes and Tribes of Southern India, vi, 106.

- Bombay Gazetteer, xxi, 613.

- R. V. Russell, District Gazetteer, Nimār, i, 227.

7 Journ. Roy. Anthrop. Inst, xxxii, 454. 
of an impure garment should defile the food. ${ }^{1}$ The Porojā or Parjā women of Vizagapatam and Ganjam, on the east Madras coast, are said to wear clothing in their houses, but leave it off when they go outside; "it seems that the tabu is directed against appearing in public fully clothed, and not against wearing decent sized clothes as such."2 .

Practices such as have been described in this paper are naturally a fruitful theme for ætiological legend. The Juāngs of Chotā Nãgpur say that " the river goddess emerging for the first time from the Gonasikā river, came suddenly on a rollicking party of Juāngs dancing naked, and ordering them to adopt leaves on the moment as a covering, laid on them the curse that they must adhere to that costume for ever or die."3 The Gadabā women in Madras wear cloth made of tree fibre because Sìtā, consort of Rāma, wore similar clothing in the forest; some of them laughed at her, and she cursed them that ever afterwards they should wear no dress but fibre cloth.4 A Kanara story runs that the headmen of a certain village were once upon a time taken naked for execution on the seashore; but in their shame they gathered leaves of the "five-leafed" trees and made themselves aprons, whereupon their guards in pity released them, and since then they have worn nothing else. ${ }^{5}$ The Devāngā weavers say that Vishnu gave to one of their ancestors some fibres of the lotus flower that grows from his navel, and taught them how to make clothes for gods and men; it was this culture hero who instructed his descendants in the art of making fibre cloth. ${ }^{6}$

1 F. R. Hemingway, District Gazetteer, Godàvarī, i, 55.

2 Thurston, Castes and Tribes of Southern India, vi, 219.

3 Dalton, op. cit., 156.

4 Thurston, op cit., ii, 245. Compare the story of the Porojās or Parjās, p. 240 et seq. above.

5 Oppert, op. cit., 174.

6 Thurston, op. cit., ii, 157. 